\title{
ITALIANIZING ITALY: DUBBING WOODY ALLEN'S TO ROME WITH LOVE
}

ABSTRACT. Audiovisual translation has recently established itself within the field of Translation Studies, due to the implications of adapting a movie or TV series for an audience located in a different linguacultural context. Sociocultural and linguistic interferences may hinder the comprehension and successful fruition of the product by the target audience. As a consequence, translators often have to operate choices to work within the constraints laid by the need to familiarize the viewers with the original product. The Woody Allen movie To Rome with Love is an especially relevant example of script adaptation as it is set in the Italian capital, which implicates a strong connection with the sociocultural context of the location. Adaptation of the movie into Italian, therefore, occurs on two different, intertwining levels. On the one hand, translators have to remain faithful to the original script, and on the other, they are supposed to give a target-oriented translation that might not correspond with the representation of the country provided by the screenwriters. In this paper, we will present a comparative analysis of the English and Italian scripts aimed at identifying the strategies adopted to minimize Anglo-American interferences in the target product.

KEYWORDS: audiovisual translation; Italian dubbing; To Rome with Love

\footnotetext{
valeria.franceschi@univr.it

sara.corrizzato@univr.it
}

This paper was submitted on August $13^{\text {th }}, 2019$ and accepted for publication at the meeting of the Editorial Board held on September $16^{\text {th }}, 2019$. 
Academic interest in audiovisual media flourished in the second part of the twentieth century as the number of channels used for the transmission of products developed and improved. The advent of the Video Home System (VHS), whose roots date back in the seventies, marked the beginning of a new era in which users started to have the possibility to autonomously video record on tape cassettes. This trend, who saw the spread of the home video industry, changed the viewers' perception of television and movie entertainment, allowing them to watch TV shows and films at their will. Some decades later, the Video Home System was replaced by the Digital Video Disc (DVD), a digital optical disc guaranteeing a higher picture and sound quality, and a much longer lifespan than videocassettes. In addition to the aforementioned qualities, the interactive functions of DVDs allowed users, both in the case of films, and/or TV series and video games, to develop a greater familiarity with the products, enabling them to select specific scenes, different audio tracks, and subtitles, as well as bonus material of various type (e.g. behind-the-scenes featurettes, interviews with the cast and crew, etc.). Such a huge and unprecedented revolution has also promoted various changes in the way in which audiovisual products have entered academia, which started to demonstrate a specific interest in such materials since the beginning of the $80 \mathrm{~s}$ (Freddi and Pavesi 2005; Díaz Cintas 2008; Díaz Cintas 2009; Díaz Cintas and Anderman 2009). Visual and verbal components of the products have been fully recognized as a valuable source to study society from multiple angles giving life to a huge number of interdisciplinary studies, whose aim is to investigate audiovisuals from different linguistic and socio-cultural perspectives in heterogeneous materials, such as films, TV series, documentaries, television programs and video games. As Díaz Cintas (2004, p. 31) highlights, "the linguistic and cultural approaches should not be viewed as antagonistic paradigms but, rather, complementary", as "an audiovisual text is a communication act involving sounds and images" (Zabalbeascoa, 2008, p. 21) that reproduces specific traits of the community to which it belongs.

Apart from the undisputed role audiovisuals have in understanding communities of speakers and their cultural diversity, there has been a growing interest in the language itself: audiovisual products 
indeed "comprise useful material for an in-depth study of face-to-screen dialogue as examples of everyday language, providing a faithful representation of real language" (Corrizzato, 2015, p. 29). As a consequence, audiovisual translation (AVT) has gained the same importance in academic contexts, in which the study of different linguistic versions of the original product become extremely interesting to investigate the various ways in which the source text enters the target culture. In this regard, if research in this field was not extensive before the 90s (Díaz Cintas, 2008, p. 1), since the beginning of the $20^{\text {th }}$ century numerous volumes have been published concerning the role audiovisual translation plays in (re)shaping the original product for the target audience, taking into account dubbing and subtitling as the major translation modes ${ }^{1}$.

The growing interest in audiovisual translation has encouraged and is still encouraging experts in the field to comprehend whether and to what extent a source text has to be adapted for the target audience, which can be quite familiar with the lingua-cultural traits of the original product or cannot fully understand them. In terms of adaptation, two different, yet complementary, approaches have to be taken into account: localization and foreignization. More specifically, as Venuti (1995, p. 482) clarifies, a translator working on audiovisual products is required to negotiate "the linguistic and cultural differences of the foreign text by reproducing them and supplying another set of differences, basically domestic, drawn from the receiving language and culture to enable the foreign to be received there". With this purpose, what seems to be the most relevant aspect to be considered is the degree of "domestification" (Venuti, 1995) that the 'new' material has to include. Such a characteristic, which is covertly embedded in the end-product, is the result of a series of complex choices taken by the translator in relation to the original text. Although the translation is supposed to be "a reproduction, a copy, a replica, a mirror image of the orig-

1 A closer look at bibliography on research in audiovisual language (AVL) and in AVT shows that several eye-opening volumes and articles have been published in the last decades both in the international context (Díaz Cintas 2008; Díaz Cintas 2009; Díaz Cintas and Anderman 2009; Díaz Cintas, Matamala and Neves 2010; Díaz Cintas and Neves 2015; Pérez-González 2014; Pérez-González 2018; Gambier and Ramos Pinto 2018) as well as in the Italian panorama (see among the others, Freddi and Pavesi 2005; Paolinelli and Di Fortunato 2005; Perego 2005; Ranzato 2010; Corrizzato 2016; Corrizzato 2018; Renna 2018a; Renna 2018b; Zottola 2017; Ranzato and Zanotti 2018). 
inal" (Ulrych, 2000, p. 127), it embodies a set of lingua-cultural changes that contribute to permanently modifying the target version and the way in which viewers interiorize it. Therefore, whether foreignizing, i.e. retaining the original traits of the source text as much as possible, or localizing, that is, making some significant changes to the source material to meet the target audience's needs and tastes, adaptation involves a (quite) endless number of variables specifically concerning the target viewers, such as understanding "how the target language and culture view 'the other" (Ulrych, 2000, p. 132), "reducing if not simply excluding the very difference that translation is called on to convey" (Venuti, 1995, p. 21), or respecting censorship mechanisms that may be in place in the target country (Gómez Castro, 2016).

The present investigation will offer a reflection on the different strategies adopted by translators, as the audiovisual product selected for the analysis can be considered a 'hybrid' example: To Rome with Love (Aronson, Tenenbaum \& Allen, 2012) is a romantic comedy, written and directed by Woody Allen in 2012. The movie is set in Rome, Italy. It was first released, in its dubbed version, in Italian theatres in April 2012, and only two months later, in Los Angeles and New York (Lyman, 2012, 13 April). In the original version, Allen's film includes some scenes in which two languages coexist: English and Italian, as two of the youngest characters, and their families, involved in the plot do not share the same lingua-cultural background. Several are therefore the situations in which the young couple is asked to help their parents to understand what is said in the language they do not speak. In addition to the linguistic constraints, the location itself, Rome, can contribute to making adaptation more complex due to the fact that cultural references are inevitably embedded in the Italian culture. As a matter of fact, translating the original script in another language, rather than into Italian, could be an easier process because both bilingualism and lingua-cultural references could be maintained or neutralized to fulfil the target audience's needs. In the case of the Italian adaptation, the same process could be a paradox: the original American version has to be adapted to Italian viewers, who are familiar with the Italian language used in some scenes and with the cultural context more than the audience of the source version. 


\section{RESEARCH QUESTIONS AND METHODOLOGY}

Our goal for this analysis is to explore three main issues related to the audiovisual translation into a target language and culture that occurs and plays a significant role in the original product.

Specifically, we set out to investigate whether and to what extent:

1) bilingualism (English - Italian) of the original text has been maintained in the Italian dubbed version

2) the sociocultural context of the location forces processes of localization (or foreignization) of the original script in the dubbed version

3) the process of harmonization between visual/non-verbal components and verbal elements of the original product is adapted/ modified in the target version

A viewing of the dubbed version of the movie quickly provided the answer to the first point: the Italian version was dubbed in its entirety, effectively erasing the instances of code-switching appearing in the original version and the language barrier between English-speaking and Italian-speaking characters. A close analysis of the two versions of the script has been carried out in order to investigate the following two points, with an attention to the adaptation strategies employed.

The movie tells four unrelated, but intertwining, stories:

- a worker who wakes up to find himself a celebrity (Leopoldo's story)

- an architect who takes a trip back to the street he lived on as a student (John's story)

- a young couple on their honeymoon (Antonio's story)

- a frustrated opera director who has a talent for discovering talented singers (Hayley's story)

The latest story is the one our analysis focuses on: Hayley is a tourist who meets and falls in love with Italian lawyer Michelangelo. When they become engaged, her parents, Jerry and Phyllis, fly to Rome to meet Michelangelo and his family. Jerry, a retired opera director, is amazed by Michelangelo's father's voice and wants him to sing on an actual stage, which creates tensions between the two 
families. This storyline is the most significant in terms of our investigation: indeed, the original version includes instances of code-switching and translations that cannot be reflected in the dubbed version and had to undergo significant adaptation.

\section{FINDINGS}

Before looking specifically at examples from the script, some general observations can be made about choices made in relation to dubbing. The narrative is framed by an opening and a closing scene featuring two Roman citizens. In the original version, the characters speak English with a strong Italian accent. In the dubbed version, the characters speak Italian with a noticeable Roman regional accent. As Perego states, when characters in the original version speak the language in which the movie is being translated, a local variety may be employed in the adapted version $(2005, \mathrm{p}$. 26). The movie being set in Rome, in this case the choice of the variety is self-explanatory. The traffic warden introducing the action and the citizen providing a final comment are both local characters, and in the Italian version they contribute to creating a realist setting through geographically-localized language use. They seem omniscient-narrators, part of Rome itself rather than acting in the city. The traffic warden speaks Italian to drivers before switching into Italian and addressing the public - breaking the fourth wall. A distinctly Roman accent can be heard, which may have influenced or reinforced the choice as well.

Another observation that can be made is that in the original version the Italian characters have strong Italian accents and make minor grammatical mistakes when speaking English (e.g. "My job, as you can see, is to see that the traffic move", "I've not cleaned up"). On the other hand, in the dubbed version the American characters speak flawless, un-accented Italian without any explanation being provided in the movie. This entails a loss of realism for the Italian viewer, as it would be extremely unlikely for a couple of middle-aged Americans coming to Italy to meet their daughter's fiancé to be able to speak the language at native-level. The American characters appear to be perfectly embedded into the Italian culture, effectively erasing all aspects of linguistic and cultural negotiation that are present in the original version, as may be seen from the examples discussed in the following sections. 


\section{STEREOTYPING ITALY}

In the movie, some stereotypes can be identified that characterize Rome as seen through an American lens for an American public. For example, the film opens with the song Nel blu dipinto di blu, which is a popular song in Italy but it is also one of the Italian songs that an American audience would be likely to be familiar with. Another example is found in the realm of cuisine, as may be seen from the following example:

(1)

Reporter: E' una macchia quella che vedo sulla-sulla sua giacca?

Aldo Romano: Sì, è sugo alla marinara

R: E com'è che se l'è procurata esattamente?

A.R.: Ma a tutti lo devo dire? Stavo mangiando un piatto di rigatoni!

Ho alzato la forchetta e mi è caduta la macchia di sugo! Che vi interessa a voi? Non capisco! ${ }^{1}$

Two elements of Italian cuisine are mentioned here, sugo alla marinara (marinara sauce) and rigatoni, a type of pasta. While both exist in Italian cuisine, they are also both popular elements of Italian-American cuisine that the American audience would have experienced and would reflect a stereotyped idea of Italian cuisine. It should also be noted, that while sugo alla marinara exists in Italy, it is different from the popular marinara sauce as would be understood by the American audience. In order to localize the action, a sauce more traditional of that area could have been mentioned, such as amatriciana, or arrabbiata, but those choices would not have been as immediately relatable to the American public. Still within the realm of cuisine, we could mention Phyllis's line regarding a dish (likely an appetizer) she ate at Giancarlo and Mariangela's.

(2)

Original Version:

P: She showed me how to make these, Jerry, but, of course, she gets her mozzarella fresh every day from Naples.

1 Reporter: Is that a stain on the jacket?

Aldo Romano: Yes, it's marinara sauce.

R: How did this happen?

A.R: Do I have to tell everyone? I was eating a plate of rigatoni! I lifted the fork and sauce fell on me! What do you care? I don't understand! 
Dubbed Version:

P: mi ha fatto vedere come si fanno, Jerry, ma qui hanno la mozzarella fresca che arriva tutti i giorni da Napoli.

Phyllis mentions here that Mariangela gets mozzarella daily from Naples, but this appears to be part of a stereotypical view of Italy as a place where people still cook traditionally with high quality ingredients coming from areas they are most renowned for. The adaptation has a slightly different connotation, as it implies it is possible to obtain fresh mozzarella from Naples - as opposed to the US -, whereas the English version seems to imply that she personally buys fresh mozzarella from Naples daily.

\section{ADAPTATION STRATEGIES}

In this section, we will look specifically at the strategies adopted in order to adapt the original script into one that is completely in Italian. We can see the first adaptation at the very beginning of Hayley's story, where she first meets future fiancé Michelangelo in the streets of Rome, where she stops to ask him for directions and strikes a conversation up with him.

Original Version:

H.: Oh, uh... Scusi. Um... Fontana di Trevi?

M.: Uh... so it's two blocks...

H.: Uh-huh, two blocks...

M.: And then across the piazza.

H.: Ok, and that's Piazza Mignanell-?

M.: No.

H.: Ok, no. Piazza di Spagna is this...

M.: No. This is Piazza Venezia.

H.: OK.

M.: Look, I'll show you. Um... this is Piazza... I don't... I don't know. Uh, look, you know what? I'm going that way, I can show you.

H.: Thank you. Thank you so much. You speak very good English.

M.: That's because of my work. I visit New York often.

H.: Oh, that's where I'm from. What do you do?

M.: I'm a lawyer. And you are, let me guess, a tourist.

H.: For the summer. I'm Hayley. Hi.

M: Hi. Michelangelo.

Dubbed Version:

H.: Ah, Scusa, dov'è Fontana di Trevi? 
M.: Ecco, fai due isolati...

H.: Ahah, due isolati...

M.: E attraversi la piazza.

H.: Ok, e cioè Piazza Mignanelli?

M.: No.

H.: Ok, no. Piazza di Spagna è di là?

M.: No. Questa è Piazza Venezia.

H.: OK.

M.: Scusa, ti faccio vedere. Um... Questa è Piazza...Senti, io vado da quella parte, ti accompagno

H.: Grazie, grazie mille. Io sono americana, di New York

M.: Io per il mio lavoro ci vado spesso a New York, sai?

H.: Oh, allora la conosci bene... Che lavoro fai?

M.: Sono un avvocato, e tu? Vediamo se indovino, sei una turista.

H.: Vacanze estive. Io sono Hayley

M: Ciao, io sono Michelangelo

The Italian script mirrors the original version until Hayley makes an explicit reference to the English language. While in the original version Hayley compliments Michelangelo's proficiency in English, in the DB Hayley offers information about herself ${ }^{1}$. In the original version, New York is mentioned in Michelangelo's response, where he gives Hayley a reason for his English level. The change of topic also influences Hayley's subsequent turn: in the original version, she says she is from New York, providing that information for the first time. As this has already been established earlier, in the dubbed version Hayley comments with a move that has no correspondence in the original, before the different sequence ends and both scripts proceed again with a closer adaptation.

We find more instances of such adaptation towards the end of the movie, after Giancarlo gives an opera performance in a theatre and a review is published in a local newspaper.

(4)

Original Version:

H.: Oh, goodness, they weren't very kind to my father, were they? Mich.: Uh... Wait, I think it's better you don't hear that.

H.: No, no, I can take it. Just don't tell my Dad. Thankfully, he doesn't understand a word of Italian. Mich.: Alright, um...

1 H: I'm American, from New York

M: I often go to New York because of my work, you know

$\mathrm{H}$ : Oh, then you must know the city well... 
"Except from Mr. Santoli's magnificent voice...

H.: Magnifica! (pronounced Mag-nifica)

Mar.: La più bella di tutti. La più bella voce di tutti!

Mich.: xxx "whoever imbecile..." imbecile?

H.: Yeah, imbecile.

Dubbed Version:

H.: Non sono stati molto gentili con mio padre, eh?

Mich.: Forse è meglio che io non te lo legga

H.: No, no, leggilo, però non devi dirlo a mio padre, per quanto non credo che legga i giornali italiani.

Mich.: Ok. "Ad eccezione della magnifica voce di Giancarlo Santoli..."

H.: Magnifica!

Mar.: Hai la voce più bella di tutti.

Mich.: Momento..."chiunque sia il minus habens..." Ma hai capito?

H.: Sì. Sì, ho capito.

In this scene, Michelangelo and Hayley are worried that the review of the show may be very critical of Jerry's work as an opera director-which is indeed the case-and that Jerry might find out. Hayley points out that, as her father “doesn't speak a word of Italian", it would be possible to keep this information from him. Free translation is employed in the dubbed version, as Jerry's lack of linguistic knowledge is transformed into a lack of interest for Italian newspapers ("No, no, read it, don't tell my dad though, even though I don't think he reads Italian newspapers"). In the original version, Michelangelo proceeds by reading the review directly in English so that Hayley could follow, but he appears to have a doubt on his translation of the Italian word imbecille, and asks Hayley for confirmation, which she provides in the following turn. In the dubbed version, the problematic word is replaced with the Latin expression minus habens, which carries a similar meaning to imbecile. Rather than ask confirmation about his own word choice, here Michelangelo asks Hayley if she understands the expression, obtaining a positive answer. The Latin idiom appears again in the movie in a later scene, always as the adaptation of imbecile:

Original Version:

J: Phyllis, the reviews were so great. I mean, the press... wh-...the press called me, um...not... not, what's the word they used? Not a maestro, but uh...uh... an imbecille!

(to Phyllis) I... What... what does it mean? 
P.: Means you're ahead of your time.

J.: Ahead... you know, your mother, I'm happy to say, lucky woman, married an imbecille.

Dubbed Version:

J.: Phyllis le recensioni sono tutte eccezionali, insomma, La stampa, come mi ha chiamato la stampa? No no no no, quale parola hanno usato? Non era maestro ma era un un...minus habens!! (a Phyllis) Mi hanno bocciato in latino, che vuol dire?

P.: Vuol dire che precorri i tempi.

J.: Ahh ecco, tua madre, sono felice di dirlo, ha avuto la fortuna di sposare un minus habens.

In this scene, Jerry is boasting about his show receiving positive reviews, clueless about the true content of the article. When he asks Phyllis about the meaning of imbecille, she mitigates her answer with a white lie. In the dubbed version, the line is longer and provides a plausible motivation for Jerry's question. The adaptation exploits the Latin origin of the idiom, which Jerry does not understand due to having failed Latin in school.

\section{TRANSLATING FOR AN ITALIAN SPEAKER}

In the storyline under investigation, not all the Italian characters can communicate in English, other characters therefore step in and provide a translation as to keep the non-English speaking character informed of the events. However, language alternation is not present in the Italian adaptation, which entailed a number of free translation choices, illustrated in the following examples.

The first takes us back to Michelangelo's parents' house. He and Hayley are now engaged and her parents travelled to Rome to meet Michelangelo and his family. In this conversation, the lack of code-switching in the dubbed version involves a shift in the relationship between Michelangelo's father and mother, as will be seen in the example below:

Original Version:

G.: Please, come in. Mariangela vieni! Sono arrivati i genitori di Hayley!

P.: Oh, hello!

G.: Phyllis, Jerry. 
P.: So nice to meet you.

M.: Buongiorno.

G: Oh, Mariangela don't speak good English.

P.: No...

M.: No.

$\mathrm{J}$ hands her a bottle of wine

M: *whispers* Grazie.

G.: What you drink?

P.: Well... wine would be great.

G.: Wine. Michelangelo and Hayley should be here any minute but if you excuse me now I need to go to clean up.

Mariangela, um, apri la bottiglia e... porta da bere.

M.: Vado ad aprire questa qui, intanto voi sedetevi pure, accomodatevi, torno subito.

Dubbed Version:

G.: Prego, accomodatevi! Mariangela vieni! Sono arrivati i genitori di Hayley!

M.: Oh, Salve, piacere.

P.: Molto piacere.

G.: Phyllis e Jerry.

M.: Buongiorno

L.: Lei non si sa comportare, da noi non viene mai nessuno

P.: Ah, no.

M.: Beh, no.

J.: Oh, Ecco. *hands bottle of wine to Mariangela*

M.: Grazie.

G.: Che cosa bevete?

P.: Vino, il vino va benissimo.

G.: Michelangelo e Hayley arrivano tra pochissimo. Scusate ma io devo proprio andarmi a lavare, è d'obbligo!

Mariangela, eh, apri la bottiglia e porta da bere.

M.: Vado ad aprire questa qui, intanto voi sedetevi pure, accomodatevi, torno subito.

In the original version, switches occur multiple times in this brief scene where Hayley's parents visit Michelangelo's parents and meet Michelangelo's mother, Mariangela, who, as mentioned by Giancarlo, does not speak English. Mariangela indeed only uses Italian in her dialogues, greeting the American couple with Buongiorno and confirming her lack of knowledge of the language with a ' no' following Phyllis' move. However, in the Italian version, Mariangela's character undergoes a change and information about her relationship with her husband is provided that does not exist in the original version. The conversation about Mariangela's English 
skills, superfluous in the dubbed version where everybody speaks perfect Italian, is transformed into one about her interpersonal and hosting skills, with Giancarlo making a jab about her being unable to behave properly in company. In addition, a two-turn sequence is made more prominent in the dubbed version, when Jerry hands Mariangela a bottle of wine with 'oh, ecco' and Mariangela whispers 'grazie. Jerry mouths something inaudible in the original version when he hands Mariangela the wine, so the louder equivalent in Italian is well synched with the visual dimension of the scene. Mariangela's lack of English knowledge entailed other instances of adaptation when, in other moments during the movie, his son or husband translated information for her, as may be seen in the excerpts below:
Original Version:
G.: What do you do, Phyllis?
P.: I'm a psychiatrist.
G.: Oh. E' una psichiatra.
Dubbed Version:
G.: E tu che cosa fai Phyllis?
P.: Sono una strizzacervelli
G.: Oh. E' una psichiatra.

In (7), Giancarlo asks Phyllis about her job. When she provides an answer, in the original version Giancarlo translates the information into Italian for Mariangela. In order to justify Giancarlo's repetition of the job in the dubbed version, a choice was made to use a connoted, informal synonym of psychiatrist (strizzacervelli, i.e. shrink) in Phyllis's line. The use of this word may similarly influence the perception of the character, as this lexical choice adds a layer of self-deprecatory humor to Hayley's mother.

(8)

Mariangela is not in the frame

Original Version:

Mich.: Look. He already said no.

(to Mariangela) Vuole che papà canti per una casa discografica, non lo so.

(to Jerry) Dad's not a singer. I'm sure you don't want him to make a fool of himself.

Dubbed Version:

Mich.: Senti, ha già detto di no. 
Mar.: Michelangelo, ma il signore...

Mich.: (a Mariangela) Mamma, con papa è inutile insistere, lo sai. (a Jerry) Papà non è un cantante. Non vorrai fargli fare una brutta figura.

In example (8), a tense conversation takes place between Michelangelo and Jerry, who has discovered Giancarlo's talent for opera singing and wants him to sing professionally. During their altercation, Michelangelo turns to his mother, who is not in the frame, and switches to Italian so he can inform her of the topic of the conversation. In the dubbed version, Mariangela's absence from the frame is exploited by adapters to justify the repetition of information that would otherwise be redundant in the scene. Here, Mariangela appears to try and ease the tension with a turn that is not present in the original version, but she is interrupted by Michelangelo's line, which in the dubbed version acts as a reminder of Giancarlo's assertiveness ("Mom, you know it's useless to insist with dad").

\section{DISCUSSION AND CONCLUSION}

As could be seen from the examples analysed in this paper, the aspect of code-switching that characterized parts of the movie in its original version - specifically Hayley's story - disappeared entirely from the dubbed version, as the latter operated under the assumption that all characters, including the American characters, spoke flawless, unaccented Italian. As the other stories did not involve significant portions of code-switching or instances of dialogues where the linguistic barrier caused miscommunication or the need for translation, our examples came almost exclusively from the Hayley and Michelangelo storyline. Many of the implications connecting to bilingualism are neutralized with the strategies illustrated above - the adaptation also exploited the visual characteristics of the movie, such as the lack of a person in the frame to add a line of speech that wasn't there in the original version (example 8). Constraints connected to the interaction of the two languages have been similarly neutralized, with uses of free translation that added elements of characterization to characters, adding a humorous side to Phyllis, a lack of interpersonal abilities for Mariangela, and possibly a lack of respect for her on Giancarlo's part; all aspects that were not originally intended. The movie shows an American-filtered representation of Italy, as shown from the use of 
certain stereotypical elements present in the film, such as the music choice in the opening, Giancarlo's and the traffic warden's strong accents, and one of the storylines being based around opera. This is in line with Woody Allen's own viewpoint, as stated by the filmmaker himself at the Press Conference given in 13 April 2012: "When I come to a place to make a movie I give you my own impression of it, the things that strike me as dramatic or comic, that would be fun to see. I have no great insights at all into Italian politics, Italian culture, I just try and make a movie that will be set in Rome and that will be entertaining for people to see. I don't know enough to be able to teach anybody anything or to, as I said to have any insights about the culture" (Lyman, 2012, 13 April) The same message is reiterated in an interview given for the Italian website of the entertainment magazine TV Sorrisi e Canzoni: "Nessuno mi ha detto nulla sulla politica e la cultura italiane. Volevamo mostrare Roma nel modo in cui la vede un turista americano, solo un'impressione, che può essere accurata o meno, ma che rimane un'impressione Americana". ${ }^{1}$ However, despite all those elements indicating an American perspective on Rome, the adaptation of the movie into Italian has, in a certain sense, "avoided" emphasis on this American-filtered representation through a prevalently target-oriented translation; this choice effectively erased the linguistic and cultural barrier that is present in the original version by turning the American characters into native-like speakers of Italian, giving viewers the perception of watching an American comedy like many others, rather than one set in a specific geographical and cultural setting.

REFERENCES Aronson, L. \& Tenenbaum, S. (Producers), \& Allen, W. (Director). (2012). To Rome with Love. [Motion Picture]. United States: Medusa Film.

Corrizzato, S. (2015). Spike Lee's Bamboozled: A Contrastive Analysis of Compliments and Insults from English into Italian. Newcastle upon Tyne: Cambridge Scholars Publishing.

Corrizzato, S. (2016). Strategies of Glocalization in Audiovisual Translation: Dubbing Ava Duvernay's Selma into Italian. Iperstoria, 8, 33-43. Retrieved

1 "Nobody ever told me about Italian culture and politics. We wanted to show Rome in the way an American tourist sees it, just an impression that may be more or less accurate, but that ultimately remains an American impression." http://www.sorrisi.com/cinema/woody-allen-lintervista-\%C2\%ABscamarcioha-davvero-carisma-benigni-e-stato-sottile\% $\mathrm{C} 2 \% \mathrm{BB} /$ The link is no longer active. 
from http://www.iperstoria.it/joomla/images/PDF/Numero_8/monografica_8/Sara\%20Corrizzato_intestato.pdf

Corrizzato, S. (2018). "Freeze, Miami Vice”: sull'adattamento lingua-culturale in italiano della prima stagione della serie TV. In: S. Rosso \& M. Dossena (Eds.), Mondi e modi della traduzione (72-92). Verona: Ombre Corte.

Díaz Cintas, J. (2004). In Search of a Theoretical Framework for the Study of Audiovisual Translation. In: P. Orero (Ed.), Topics in Audiovisual Translation (21-34). Amsterdam/Philadelphia: John Benjamins.

Díaz Cintas, J. (Ed. (2008). The Didactics of Audiovisual Translation. Amsterdam/ Philadelphia: John Benjamins Publishing Co.

Díaz Cintas, J. (Ed.). (2009). New Trends in Audiovisual Translation. Bristol/Buffalo/Toronto: Multilingual Matters.

Díaz Cintas, J. \& Anderman, G. (Eds.). (2009). Audiovisual Translation. Language Transfer on Screen. Basingstoke: Palgrave Macmillan.

Díaz Cintas, J. \& Neves, J. (Eds.). (2015). Audiovisual Translation: Taking Stock. Newcastle upon Tyne: Cambridge Scholars Publishing.

Díaz Cintas, J., Matamala, A., Neves J. (Eds.). (2010) New Insights into Audiovisual Translation and Media Accessibility. Amsterdam/New York: Rosopi.

Freddi, M. \& Pavesi, M. (2005). Analysing Audiovisual Dialogue. Linguistic and Translational Insights. Bologna: CLUEB.

Gambier, Y. \& Ramos Pinto, S. (Eds). (2018). Audiovisual Translation: Theoretical and Methodological Challenges. Amsterdam: John Benjamins.

Gómez Castro, C. (2016). Ideological Manipulation in the Form of Official Censorship: Audiovisual Tie-ins of Bestselling Novels in Spain under Franco. Altre Modernità, 2, 42-57.

Lyman, E. J. (2012, 13 April). Woody Allen’s ‘To Rome With Love’ Draws Mixed Response in Italy at World Premiere. The Hollywood Reporter. https:// www.hollywoodreporter.com/news/woody-allen-to-rome-with-love-italian-premiere-312013

Paolinelli M. \& Di Fortunato, E. (2005). Tradurre per il doppiaggio. La trasposizione linguistica dell'audiovisivo: teoria e pratica di un'arte imperfetta. Milan: Hoepli.

Perego, E. (2005). La traduzione audiovisiva. Rome: Carocci Editore.

Pérez-González, L. (2014). Audiovisual Translation: Theories, Methods and Issues. London: Routledge.

Pérez-González, L. (Ed.). (2018). The Routledge Handbook of Audiovisual Translation. London: Routledge.

Ranzato, I. \& Zanotti, S. (Eds.). (2018). Linguistic and Cultural Representation in Audiovisual Translation. London: Routledge.

Ranzato, I. (2010). La traduzione audiovisiva. Rome: Bulzoni Editore. 
Renna, D. (2018a). Re-shaping Languages nd Stereotypes in Dubbing. In: S. Barschdorf \& D. Renna (Eds.), Translating Bounderies. Constraints Limits Opportunities 233-260. Stuttgart: Verlag.

Renna, D. (2018b). Bandidos e Chicano Gangsters: stereotipi linguistici nel cinema americano e nel doppiaggio italiano. In: S. Rosso \& M. Dossena (Eds.), Mondi e modi della traduzione 93-115. Verona: Ombre Corte.

Ulrych, M. (2000). Domestication and Foreignification in Film Translation. In: C. Taylor (Ed.), Tradurre il cinema 127-144. Trieste: Dipartimento di Scienze del Linguaggio, dell'Interpretazione e della Traduzione.

Venuti, L. (1995). The Translator's Invisibility: A History of Translation. London: Routledge.

Zabalbeascoa, P. (2008). The Nature of the Audiovisual Text and its parameters. In: J. Díaz Cintas (Ed.), The Didactics of Audiovisual Translation 21-38. Amsterdam/Philadelphia, John Benjamins.

Zottola, A. (2017). Legal Drama and Audiovisual Translation: The Role of Legal English in the Construction of Stereotyped Representations. Studies in Logic, Grammar and Rhetoric, 49 (62), 247-268. Doi: 10.1515/slgr-2017-0015

ВАЛЕРИЈА ФРАНЧЕСКИ

САРА КОРИЦАТО

УНИВЕРЗИТЕТ У ВЕРОНИ

ДЕПАРТМАН ЗА ЈЕЗИКЕ И КњИЖЕВНОСТИ

ИТАЛИЈА

РЕЗИМЕ

\author{
ИТАЛИЈАНИЗАЦИЈА ИТАЛИЈЕ: СИНХРОНИЗАЦИЈА ФИЛМА \\ РИМУ, С ЉУБАВљУ ВУДИЈА АЛЕНА
}

Аудиовизуални превод пронашао је своје место у теорији превођења захваљујући импликацијама и утицајима које синхронизација филма или телевизијске серије има на гледаоце из другог лингвокултуролошког контекста. Друштвено-културолошки и лингвистички фактори могу утицати на разумевање и успешно прихватање производа од стране циљне публике. Из тог разлога, преводиоци често морају да бирају функционална решења у оквиру ограничења наметнутих потребом да се гледаоци упознају са изворним производом. Филм Риму, с љубављу Вудија Алена нарочито је значајан као пример адаптације будући да се радња дешава у главном граду Италије, што указује на снажне утицаје друштвено-културолошког контекста места дешавања. Стога, може се рећи да је адаптација филма на италијан- 
ски језик извршена на два међузависна нивоа. Док, с једне стране, преводиоци морају остати верни изворном тексту, с друге стране, од њих се очекује да понуде превод усмерен циљној публици који потенцијално није у складу са представама које су о земљи имали и желели да пренесу сценаристи. У овом раду представићемо компаративну анализу енглеског и италијанског текста са циљем идентификације стратегија којима се минимализује англо-америчка интерференција у крајњем производу.

КљУчнЕ РЕчи: аудиовизуални превод; синхронизација на италијански; Риму, с љу $а$ ављу.

Овај чланак је објављен и дистрибуира се под лиценцом Creative Commons Ауторство-Некомерцијално Међународна 4.0 (СC BY-NC 4.0 |

https://creativecommons.org/licenses/by-nc/4.0/).

This paper is published and distributed under the terms and conditions of the Creative Commons Attribution-NonCommercial International 4.0 licence (CC BY-NC 4.0 | https://creativecommons.org/licenses/by-nc/4.0/). 